\title{
Assessment of the Air Pollution Level in the City of Rome (Italy)
}

\author{
Gabriele Battista *, Tiziano Pagliaroli, Luca Mauri, Carmine Basilicata \\ and Roberto De Lieto Vollaro \\ Department of Engineering, University of Roma TRE, via della Vasca Navale 79, Rome 00146, Italy; \\ tiziano.pagliaroli@gmail.com (T.P.); luca.mauri@uniroma3.it (L.M.); carmine.basilicata@uniroma3.it (C.B.); \\ roberto.delietovollaro@uniroma3.it (R.D.L.V.) \\ * Correspondence: gabriele.battista@uniroma3.it; Tel.: +39-06-5733-3289
}

Academic Editor: Pietro Buzzini

Received: 20 May 2016; Accepted: 19 August 2016; Published: 23 August 2016

\begin{abstract}
Exposure to pollutants is usually higher in cities than in the countryside. Generally, in the urban areas pollution sources as traffic, power generator and domestic heating system are more intense and spatially distributed. The pollutants can be classified as a function of long-term toxicological effects due to an exposure and inhalation. In the present work, several kinds of pollutants concentration generated in Rome during 2015 have been analyzed applying different advanced post-processing technique. In particular, statistic and cross-statistic have been computed in time and phase space domain. As main result, it is observed, as expected, that all the pollutant concentrations increase during the winter season into a couple of time ranges despite of $\left[\mathrm{O}_{3}\right]$ that has high values in summer. It can be clearly concluded that Rome has a strongly unsteady behaviour in terms of a family of pollutant concentration, which fluctuate significantly. It is worth noticing that there is a strong linear dependence between $\left[\mathrm{C}_{6} \mathrm{H}_{6}\right]$ and $[\mathrm{NO}]$ and a more complex interdependence of $\left[\mathrm{O}_{3}\right]$ and $\left[\mathrm{C}_{6} \mathrm{H}_{6}\right]$. Qualitatively is provided that, to a reduction of $\left[\mathrm{C}_{6} \mathrm{H}_{6}\right]$ under a certain threshold level corresponds an increase of $\left[\mathrm{O}_{3}\right]$.
\end{abstract}

Keywords: air quality; emissions; pollutant; statistic analysis; domestic heating; urban traffic; human exposure

\section{Introduction}

Outdoor air pollution has myriad sources, both natural and anthropogenic. It is a mixture of mixtures, and the mix of contaminants in outdoor air varies widely in space and time, reflecting variation in its sources, weather, atmospheric transformations and other factors. In any particular place, the pollution in outdoor air comes not only from local sources, but also from sources that affect air quality regionally and even globally [1]. The main reason for the air quality problems is urban population growth, because people are constantly moving from rural to urban areas [2]. The air pollutants result higher in urban area because of a combination of many elements such as industrial activities, energy production plants and domestic heating [3]. They are noticeable by the toxicological effects resulting from long-term exposure via inhalation [4].

The major pollutants produced are related to human activities, especially those produced by combustion and industrial processes. The International Agency for Research on Cancer (IARC) focused the attention on the human exposures to PM (Particulate Matter). The risk of being exposed to a mixture of pollutants depends on particulate matter smaller than $2.5 \mu \mathrm{m}$, which is a common useful indicator [4]. Therefore, the $\mathrm{PM}_{2.5}$ can be taken as indicator of population exposure to outdoor air pollution. In 2010, 3.2 million of people died because of cardiovascular disease, caused by the exposure 
to ambient fine particles $\left(\mathrm{PM}_{2.5}\right)$ and 22,300 people died because of lung cancer. China and East Asia show the largest number of people who lost their life $[5,6]$.

With reference to $\mathrm{NO}_{2}, \mathrm{SO}_{2}$ and (PMs) there is general agreement in the scientific literature that they are the main agents responsible for the damage encountered on monuments and historical buildings in urban areas [7]. Atmospheric composition is of unquestionable importance in the study of the damage produced on building materials of artistic interest, since it directly influences the species characteristics and entity of the degradation mechanism occurring on the cultural heritage.

The urban areas modified the environmental features that contributed to the increase of pollution. As a matter of fact, the large concentration of the built environment, road pavement and the high building materials capacitance changed the local micrometeorological conditions. Air temperature, humidity and wind velocity and direction are altered in the urban environment compared to rural areas. Furthermore, road traffic, domestic heating, industrial activities and lack buildings energy performance involves high discomfort for users [8-20]. Besides the increase of pollutions, urbanization has led to an increase of the urban heat island intensity (spatially-averaged surface or air-temperature difference between an urban and surrounding rural area(s) [21]). Several studies are focused to reduce the urban heat island effect with different mitigation techniques [22-28].

The people exposed to air pollutants are even more evident considering the weak ventilation, because of the presence of high buildings with a consequent reduction of the dispersion of air masses. For this reason, the contaminants formed below the building height remain at the pedestrian level and increase the health damages especially during thermal inversion episodes. Several studies were conducted to analyse the correlation between the street canyon features and the pollution dispersion [29]. If the ratio between the average height of the buildings $(\mathrm{H})$ and the width of the canyon (W) is high enough to establish skimming flow conditions (at least higher than 0.65), the retention of pollutants within the urban canopy layer will be amplified [30]. The major street canyons in the cities have high value of the ratio $\mathrm{H} / \mathrm{W}$ with a consequent established helical vortex with an axis parallel to the canyon direction. In this case, the pollutants that go out of the canyon are reduced [31].

The identification of analysis tools and methods, pollutant concentrations measurement, comparison with the threshold values prescribed by law, are the activities foreseen by the legislations in order to monitor the air quality and predict rehabilitation through the definition of plans of interventions.

As a first step, in order to plain a control strategy of the pollution concentration in medium and high scale cities, proper measurement and data processing are required to highlight the achievement of dangerous concentration levels of pollutants and formulate a prediction model.

Actually, the main active control strategy is based on the introduction of some limits of the urban traffic (e.g., number of the vehicles and vehicle categories that are authorized to transit). Other interventions include the increase of efficiency of the heating systems in buildings such as the replacement of traditional boilers with condensation ones integrated with more performing regulation systems based on energy load tracking.

In the present work, several kinds of pollutants concentration such as [CO], [ $\left.\mathrm{SO}_{2}\right],[\mathrm{NOx}]$, [NO], $\left[\mathrm{NO}_{2}\right],\left[\mathrm{C}_{6} \mathrm{H}_{6}\right],\left[\mathrm{PM}_{10}\right],\left[\mathrm{PM}_{2.5}\right]$ and $\left[\mathrm{O}_{3}\right.$ ] generated in Rome during 2015 have been analysed. These pollutants were taken from the Directive 2008/50/EC, the main legislation about ambient air quality. In these analyses we applied different advanced post-processing techniques. Statistic and cross-statistic have been computed in time and Fourier domain. In particular, probability distribution, Kurtosis, Skewness, Poincaré sections and cross-correlation of the different pollutants were analysed in order to assess the air pollution level in the city of Rome and the correlation of anthropogenic sources with the pollutant emission. The extreme value theory was applied to the experimental data. Especially using the generalized extreme value (GEV) distribution, several fittings of the experiment probability density functions were calculated. GEV distribution introduced by Fisher and Tippett [32] is commonly applied in environmental science to model a wide variety of natural extremes, 
including floods, rainfall, wind speeds, wave height, snow depths, earthquake, and other maxima. For the present research activity, probability density functions fitting of the pollutant concentration were calculated. The GEV distribution turned out to be very attractive mathematical tool since its inverse has an analytical form, and its parameters are can be easily estimated [33-38]. This last feature allows us to compute the return period: the likelihood of an event to occur. This post-processing strategy is common applied to pollution database to develop model. Shen et al. developed a statistical model using extreme value theory to estimate changes in ozone episodes [39].

\section{Materials and Methods}

\subsection{Characteristics of the Study Area}

Rome is the capital of Italy, and the largest city situated in the west-central part of the country. It is also one of the most populous cities in the European Union with 2.9 million residents in $1285 \mathrm{~km}^{2}$. Considering the metropolitan area of Rome, the population reaches up to 4.3 million residents in $5352 \mathrm{~km}^{2}$. With a history of more than two and half thousand years, Rome is called the Eternal City because of the number of open-air museums. It is a mixture of a modern city and a plethora of monuments, piazzas, villas, museums, churches, Egyptian obelisks, the Forum and Vatican City. Its climate is typically Mediterranean: winters are cool and humid and summers are hot and dry. In the coldest month (January) the temperature can reach about $0{ }^{\circ} \mathrm{C}$, and in the warmest months (July and August) the temperature can reach $36^{\circ} \mathrm{C}$.

The problem has two faces: there are a lot of pollutant activities and the public transport is not efficient enough to reduce the number of cars. Pedestrian and public transport are only $20 \%$ of the total mobility, while $60 \%$ of journeys are made by private means of transport; in the historical centre this modal share changes into $34 \%$ of pedestrians, $29 \%$ of public transport and $37 \%$ of private transport [40]. In order to partially solve the problem of pollution, the Government has developed a lot of policies to improve the net of the means of transport [41].

Studying the air pollutant in the city of Rome is important because there is a high density of population and for the effects of pollutant on the variety of open-air museum.

\subsection{Pollutant Legislation}

The European Union policy on air quality has the goal of implementing appropriate instruments aimed at improving air quality. The control of emissions from mobile sources, improving fuel quality and promoting and integrating environmental protection requirements into the transport and energy sector are the main goals of this policy [42].

The Directive 2008/50/EC of the European Parliament [43] is the main legislation about ambient air quality. It fixes health based standards and objectives for a number of pollutants in air. These standards are applied in different time spans because the observed health impacts associated with the various pollutants occur over different exposure times. Table 1 shows the standard adopted in the Directive 2008/50/EC.

Table 1. Directive 2008/50/EC standards of main pollutant.

\begin{tabular}{cccc}
\hline Pollutant & Concentration & Averaging Period & Permitted Excess Each Year \\
\hline $\mathrm{PM}_{10}$ & $50 \mu \mathrm{g} / \mathrm{m}^{3}$ & $24 \mathrm{~h}$ & 35 \\
$\mathrm{PM}_{10}$ & $40 \mu \mathrm{g} / \mathrm{m}^{3}$ & 1 year & - \\
$\mathrm{PM}_{2.5}$ & $25 \mu \mathrm{g} / \mathrm{m}^{3}$ & 1 year & - \\
$\mathrm{NO}_{2}$ & $200 \mu \mathrm{g} / \mathrm{m}^{3}$ & $1 \mathrm{~h}$ & 18 \\
$\mathrm{NO}_{2}$ & $40 \mu \mathrm{g} / \mathrm{m}^{3}$ & 1 year & - \\
$\mathrm{SO}_{2}$ & $350 \mu \mathrm{g} / \mathrm{m}^{3}$ & $1 \mathrm{~h}$ & 24 \\
$\mathrm{SO}_{2}$ & $125 \mu \mathrm{g} / \mathrm{m}^{3}$ & $24 \mathrm{~h}$ & 3 \\
$\mathrm{O}_{3}$ & $120 \mu \mathrm{g} / \mathrm{m}^{3}$ & Maximum daily $8 \mathrm{~h}$ mean & 25 days averaged over 3 years \\
$\mathrm{CO}$ & $10 \mathrm{mg} / \mathrm{m}^{3}$ & Maximum daily $8 \mathrm{~h}$ mean & - \\
$\mathrm{C}_{6} \mathrm{H}_{6}$ & $5 \mu \mathrm{g} / \mathrm{m}^{3}$ & 1 year & - \\
\hline
\end{tabular}




\subsection{Post Processing Techniques}

In this paper, different statistics and cross-statistics have been computed in time and Fourier domain. These correspond to time-frequency analysis that study a signal in both the time and the frequency domain simultaneously. In particular, the different techniques adopted are:

- Probability distribution describes the possible values that a random variable can take within a given range.

- Kurtosis is a measure of whether the data have a flattening or elongation from the normal distribution. High kurtosis indicates a flattering distribution, while low values indicate an elongation distribution.

- Skewness is a measure of the asymmetry of the distribution. A data set is symmetric if it looks the same to the left and right of the center point.

- Poincaré sections are a way to represent a dynamical system. The surface of section presents a trajectory in n-dimensional phase space in an (n-1)-dimensional space. By picking one phase element constant and plotting the values of the other elements each time the selected element has the desired value, an intersection surface is obtained. The phase space is a surface that describes all the possible states of a system.

- Cross-correlation is a measure of similarity of two data series as a function of the lag of one relative to the other.

- Coefficient of variation normalizes the standard deviation with the mean of a data. This index gives information about the variability of a data set.

- Generalized Extreme Value distribution is often applied to analyse a large set of data characterized by small or large value. In this approach three simpler distributions into a single form are combined, allowing a continuous range of possible shapes.

\subsection{Monitoring Station Network}

ARPA Lazio [44], the regional environmental agency, operates several air quality monitoring sites in the Lazio Region, including Rome. The Rome monitoring network consists of 10 monitoring stations of $[\mathrm{CO}],\left[\mathrm{SO}_{2}\right],[\mathrm{NOx}],[\mathrm{NO}],\left[\mathrm{NO}_{2}\right],\left[\mathrm{C}_{6} \mathrm{H}_{6}\right],\left[\mathrm{PM}_{10}\right],\left[\mathrm{PM}_{2.5}\right]$ and $\left[\mathrm{O}_{3}\right]$ that are shown in Figure 1. The monitoring network acquires concentration data every hour and every stations is set to monitor different type of concentrations. All the stations taken into account are placed inside high density urban areas that are characterized by traffic and domestic heating system pollutant sources.

The monitoring stations are constituted by fixed structures in which the entire measurement instrument, the acquisition systems and local storage are placed inside. The procedures and the control of the quality of the measures are assured by ARPA Lazio [45]. A zero value was considered when an instruments errors were found.

All the measurement instruments are made by Project Automation. Table 2 shows the sensors used for each concentration.

Table 2. Sensors used for each concentration measurement.

\begin{tabular}{ccccccc}
\hline Pollutant & PM $_{\mathbf{s}}$ & NO $_{\mathbf{x}}$ & $\mathbf{S O}_{2}$ & $\mathbf{O}_{3}$ & $\mathrm{CO}$ & $\mathbf{C}_{6} \mathbf{H}_{\mathbf{6}}$ \\
\hline \multirow{5}{*}{ Sensors } & MP101MC & & & & & \\
& SWAMDC FAI & & TE 43i & & TE 48i & AIR Toxic \\
& SWAM5a FAI & M200 A-API & & M400E API & & \\
& SWAM DC FAI & & M100E API & & M300E API & CP 7001 \\
& TE SHARP 5030 & & & & & \\
\hline
\end{tabular}




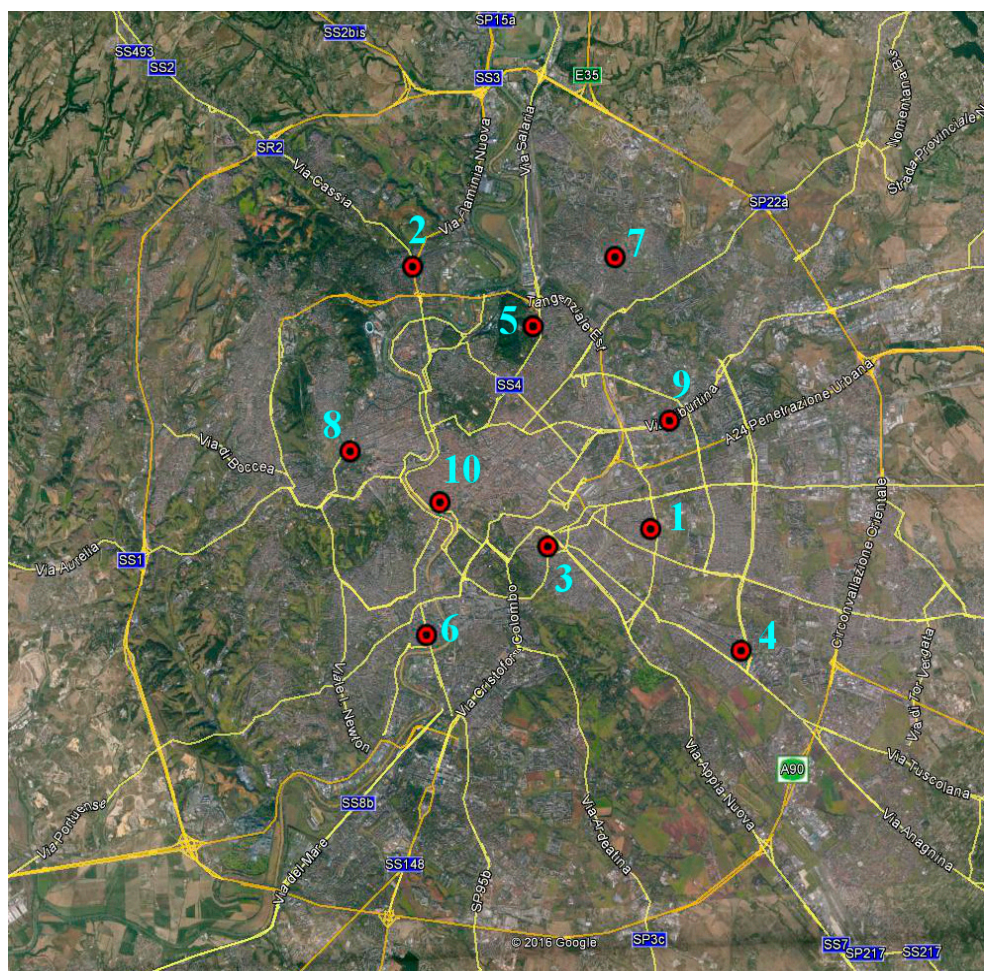

Figure 1. Google Earth map of Rome. Red circles are the monitoring stations taken into account.

\section{Results and Discussion}

In the present study, the data recorded in 2015 were considered. It is useful to consider the mean values of contaminants of each station in order to represent the average pollutant concentrations of Rome.

Before calculating the mean values concentrations of Rome, Figures 2 and 3 show the mean, standard deviation, Kurtosis and Skewness values of each pollutant during the year 2015. These are analysed in order to find the behaviour of each pollutant in the different stations. In the case of $\left[\mathrm{PM}_{10}\right]$, there is only one station that indicates a different Kurtosis value than the others. Despite this consideration, in all the concentrations the Kurtosis and Skewness values of the different stations are similar and it suggest that the mean of the network is possible.

From Figures 4-11 is shown how the mean concentration of all stations work during the year in each hour. It can been seen that the major pollutant concentrations happen in the winter seasons from 8 to 13, and from 17 to 2 , when there is a greater flow of cars in the city. The highest values are recorded from 19 to 23, when the heating systems are turned on. During the night there are lower values due to the turned off heating systems that is usually in Italy. In the summer, the high values in these hours are due to the urban traffic.

It is worth noticing that the $[\mathrm{CO}],[\mathrm{NO}],\left[\mathrm{NO}_{2}\right]$ and $\left[\mathrm{C}_{6} \mathrm{H}_{6}\right]$ have similar trend during the year suggesting the presence of pollutant source simultaneously.

The $\left[\mathrm{O}_{3}\right]$ is recorded to be higher in the summer and during the hottest hours, when the solar radiation is highest. As a matter of fact, the presence of solar radiation allows the reaction of nitrogen dioxide $\left(\mathrm{NO}_{2}\right)$ in the formation of ozone $\left(\mathrm{O}_{3}\right)$.

The $\left[\mathrm{SO}_{2}\right]$ have values up to $8 \mu \mathrm{g} / \mathrm{m}^{3}$ compared with the limit of $125 \mu \mathrm{g} / \mathrm{m}^{3}$ reported in Table 1 . That is foreseeable because the $\left[\mathrm{SO}_{2}\right]$ is mainly caused by the combustion of fuel at power plants and other industrial facilities. As a matter of fact, in the center of Rome there is not this kind of system.

The concentration of $\mathrm{PM}_{2.5}$ and $\mathrm{PM}_{10}$ has high values in the winter season and reach the maximum values in the last two months of 2015 , with values close to $50 \mu \mathrm{g} / \mathrm{m}^{3}$ of $\mathrm{PM}_{2.5}$ and values close to $70 \mu \mathrm{g} / \mathrm{m}^{3}$ of $\mathrm{PM}_{10}$. 
(a)

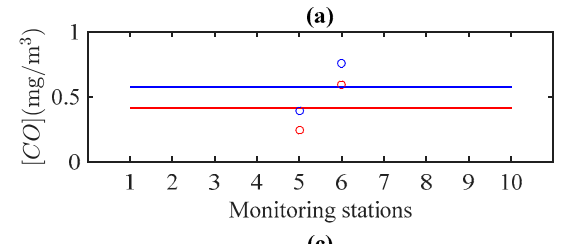

(c)

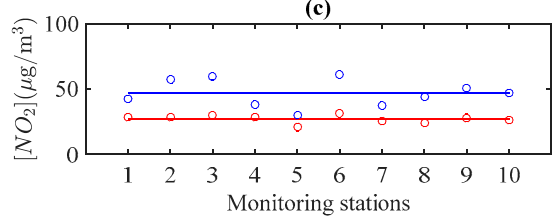

(e)

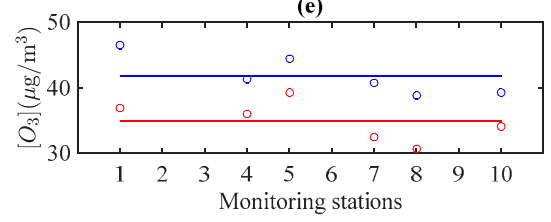

(g)

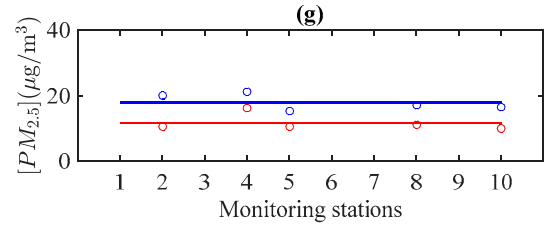

(b)

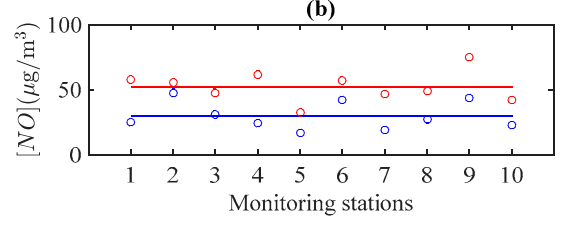

(d)

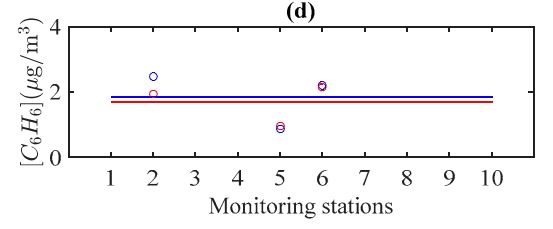

(f)

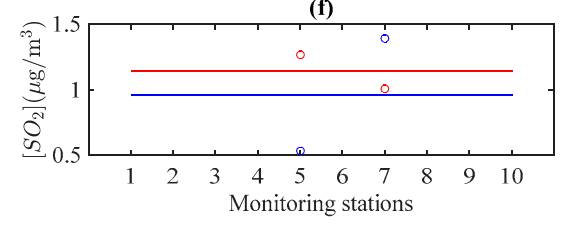

(h)

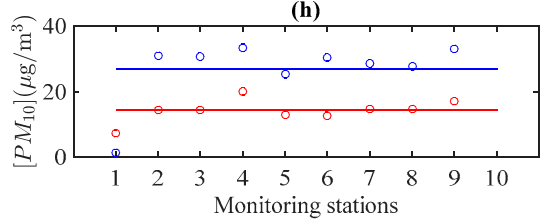

Figure 2. Mean (blue) and standard deviation (red) values calculated for all pollutant species in the different stations. Blue line is the mean of the mean values of the different stations and the red line is the mean of the standard deviation values of the different stations. (a) [CO]; (b) [NO]; (c) $\left[\mathrm{NO}_{2}\right]$; (d) $\left[\mathrm{C}_{6} \mathrm{H}_{6}\right] ;(\mathbf{e})\left[\mathrm{O}_{3}\right] ;$ (f) $\left[\mathrm{SO}_{2}\right] ;(\mathbf{g})\left[\mathrm{PM}_{2.5}\right] ;$ (h) $\left[\mathrm{PM}_{10}\right]$.

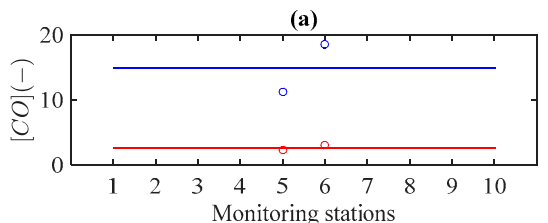

(c)

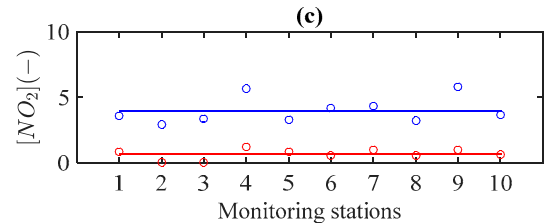

(e)

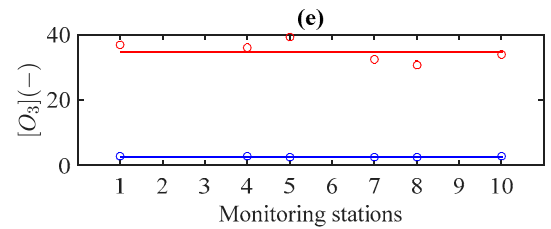

(g)

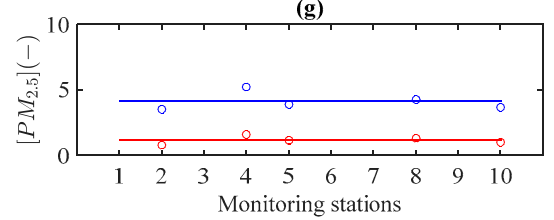

(b)

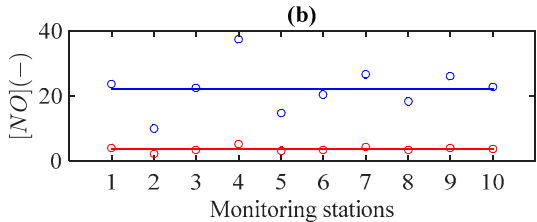

(d)

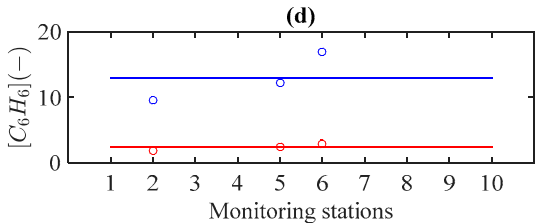

(f)

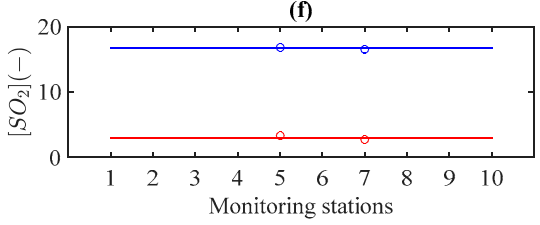

(h)

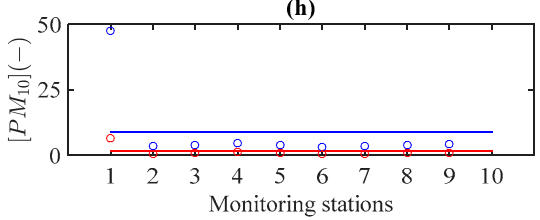

Figure 3. Kurtosis (blue) and Skewness (red) values calculated for all pollutant species in the different stations. Blue line is the mean of the Kurtosis values of the different stations and the red line is the mean of the Skewness values of the different stations. (a) $[\mathrm{CO}] ;(\mathbf{b})[\mathrm{NO}] ;(\mathbf{c})\left[\mathrm{NO}_{2}\right] ;(\mathbf{d})\left[\mathrm{C}_{6} \mathrm{H}_{6}\right] ;(\mathbf{e})\left[\mathrm{O}_{3}\right]$; (f) $\left[\mathrm{SO}_{2}\right] ;(\mathrm{g})\left[\mathrm{PM}_{2.5}\right] ;(\mathbf{h})\left[\mathrm{PM}_{10}\right]$ 


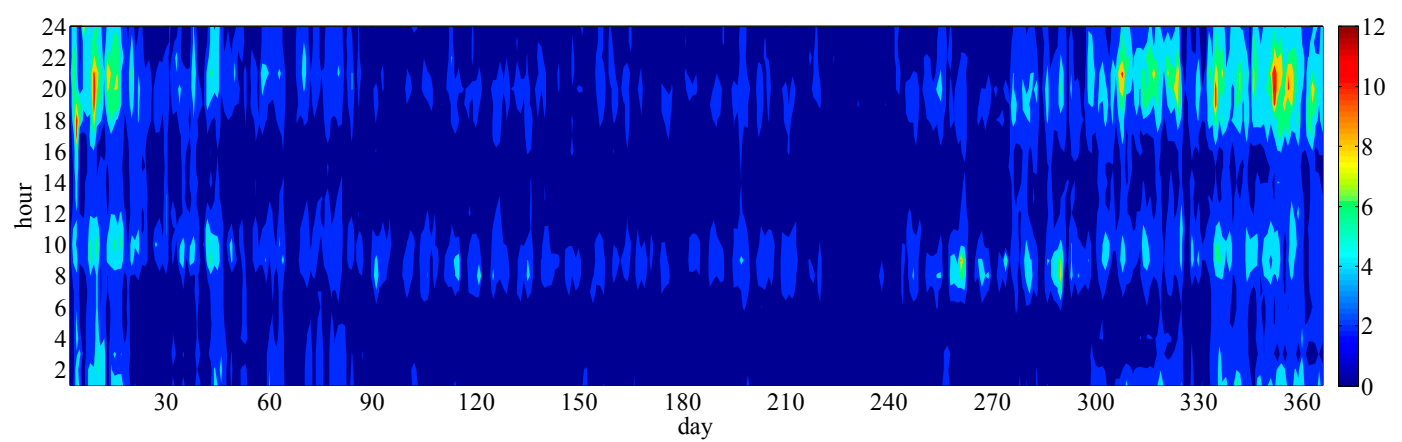

Figure 4. Hourly annual concentration variation of $\mathrm{C}_{6} \mathrm{H}_{6}$ during $2015 \mathrm{in} \mu \mathrm{g} / \mathrm{m}^{3}$.

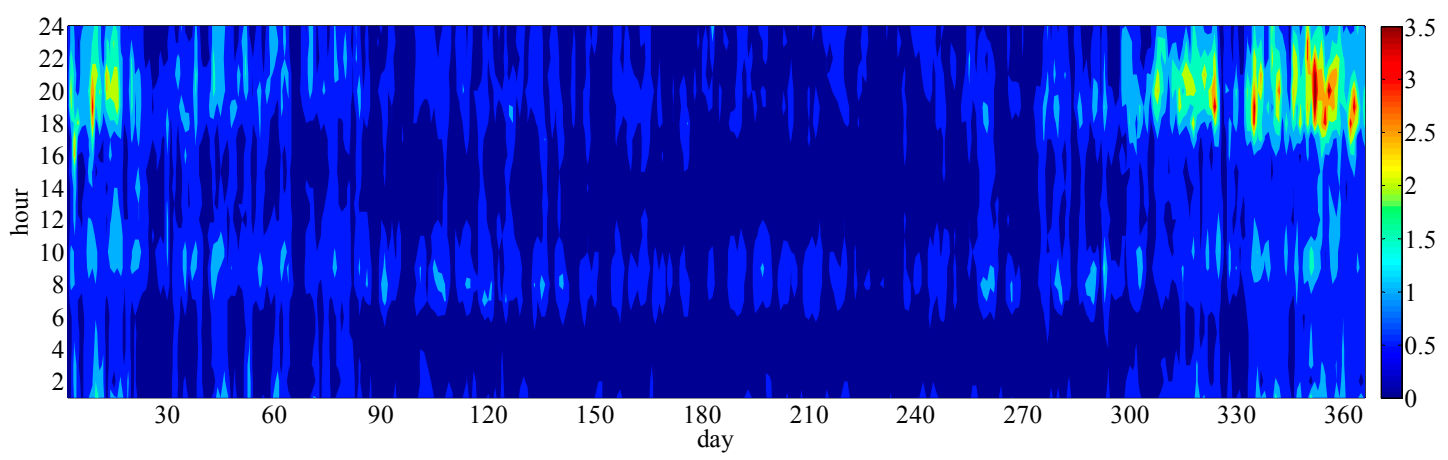

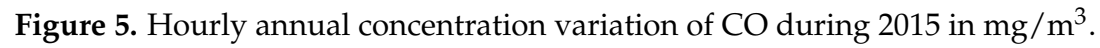

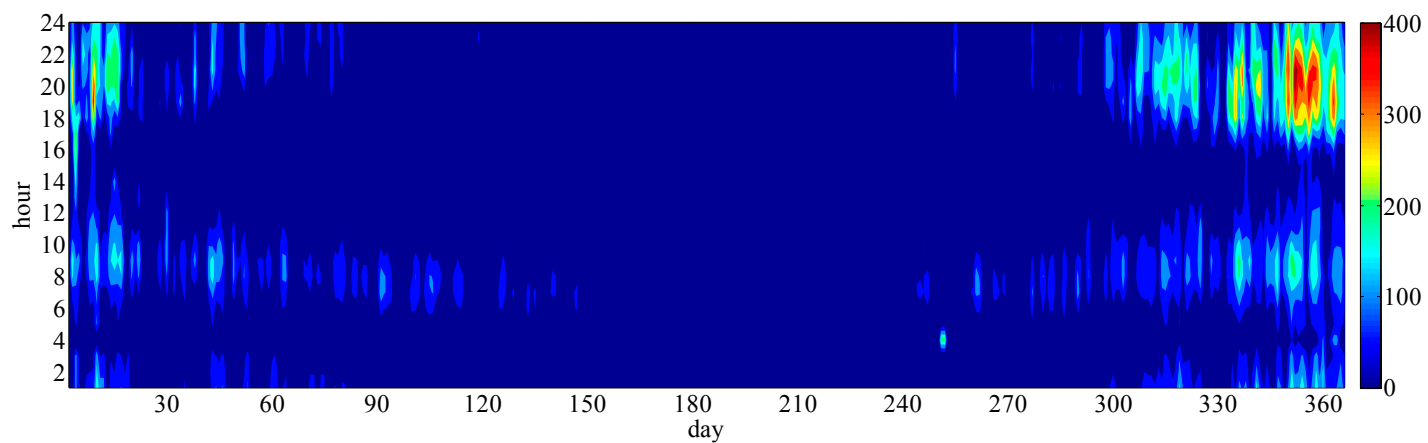

Figure 6. Hourly annual concentration variation of NO during $2015 \mathrm{in} \mu \mathrm{g} / \mathrm{m}^{3}$.

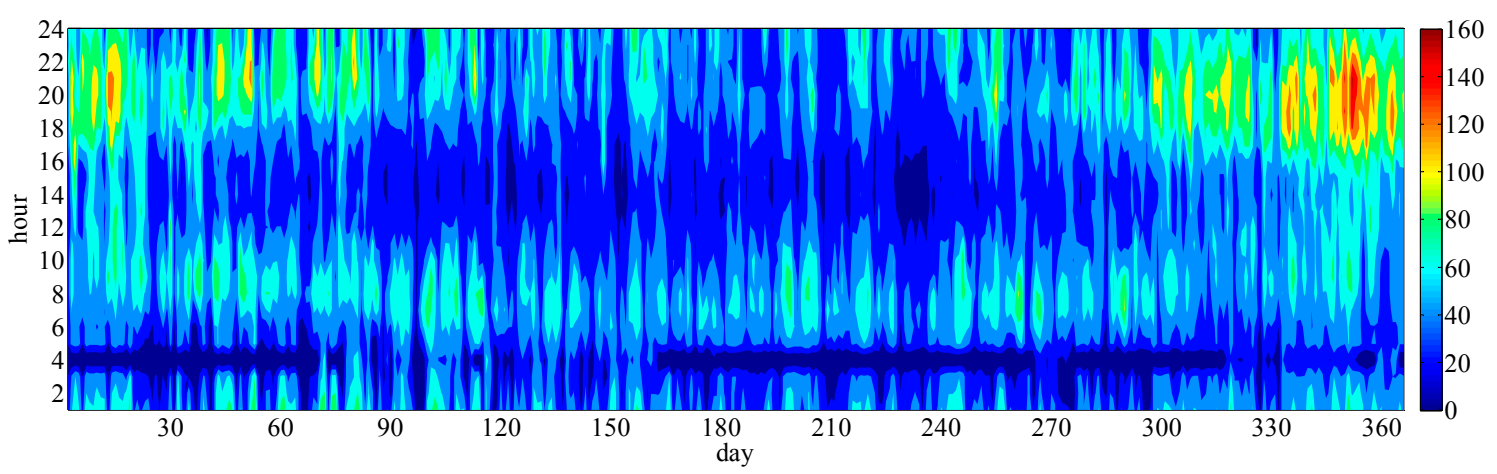

Figure 7. Hourly annual concentration variation of $\mathrm{NO}_{2}$ during $2015 \mathrm{in} \mu \mathrm{g} / \mathrm{m}^{3}$. 


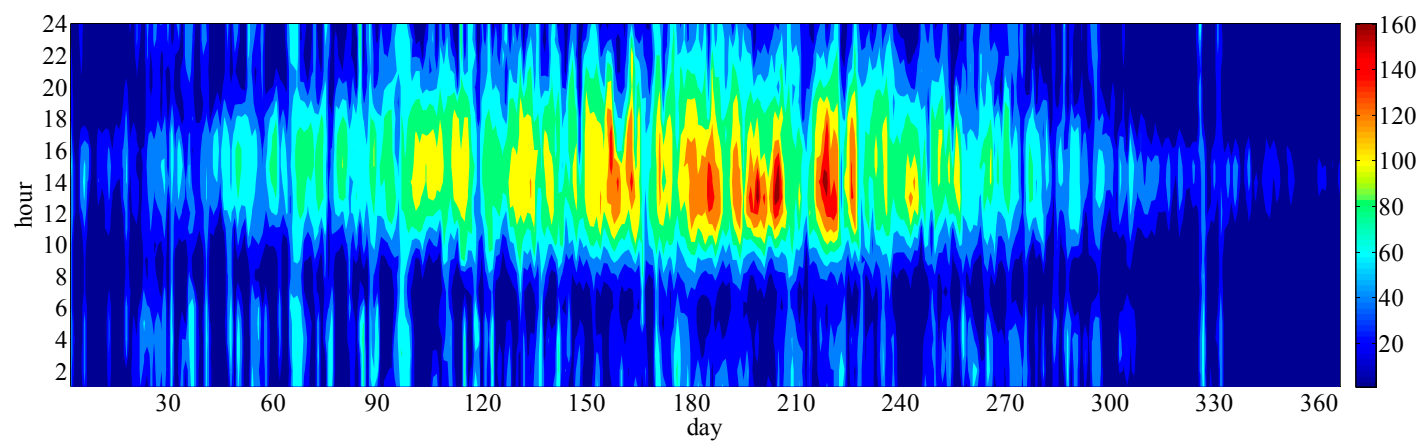

Figure 8. Hourly annual concentration variation of $\mathrm{O}_{3}$ during $2015 \mathrm{in} \mu \mathrm{g} / \mathrm{m}^{3}$.

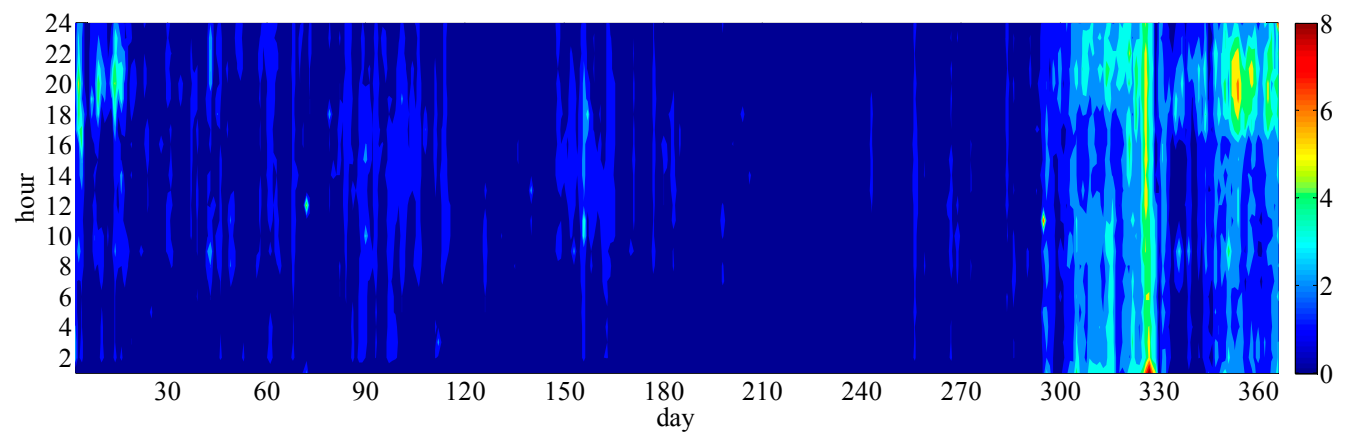

Figure 9. Hourly annual concentration variation of $\mathrm{SO}_{2}$ during $2015 \mathrm{in} \mu \mathrm{g} / \mathrm{m}^{3}$.

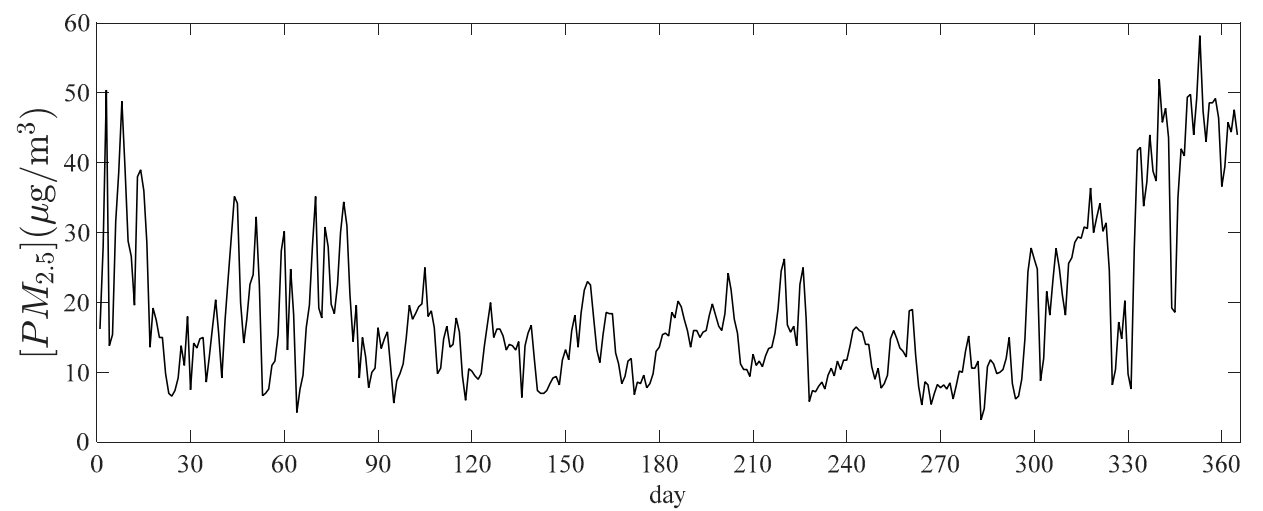

Figure 10. Hourly annual concentration variation of $\mathrm{PM}_{2.5}$ during $2015 \mathrm{in} \mu \mathrm{g} / \mathrm{m}^{3}$.

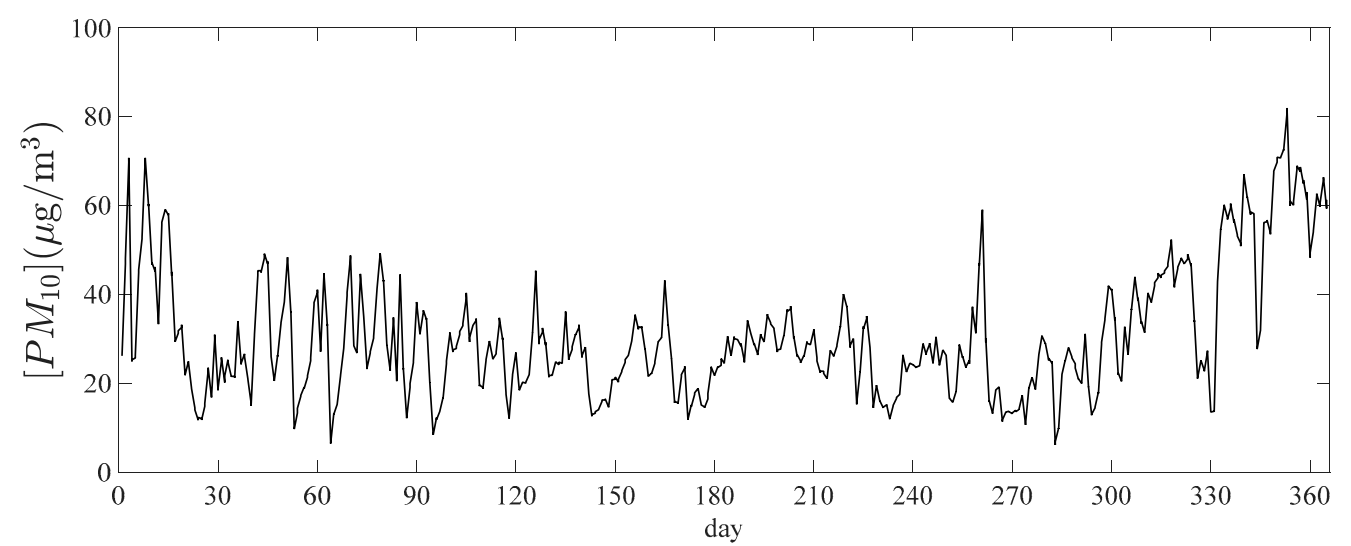

Figure 11. Hourly annual concentration variation of $\mathrm{PM}_{10}$ during $2015 \mathrm{in} \mu \mathrm{g} / \mathrm{m}^{3}$. 
The main pollutant species in terms of probability density function ( $p d f$ ) have been analysed and represented in normalized form in order to have zero mean and unitary standard deviation defined as follows:

$$
x_{\text {norm }}=\frac{x-\langle x\rangle}{\sigma_{x}}
$$

where as $\langle\cdot\rangle$ is denoted the ensemble average and as $\sigma$ is indicated the standard deviation.

It is shown in Figure 12 that $[\mathrm{CO}],[\mathrm{NO}],\left[\mathrm{SO}_{2}\right]$ and $\left[\mathrm{C}_{6} \mathrm{H}_{6}\right]$ have a narrow distribution around the most frequent value and significant positive tail. The latter aspect can be ascribed to intermittent energetic events embedded in concentration time histories. To better clarify this aspect all $p d f$ are fitted using the Generalized Extreme Value (GEV) function. By means of the GEV function, the return level and period were calculated in order to evaluate the occurrence time of these events as reported in Figure 13. With reference to the return period of [NO], every two days a high energetic peak in [NO] concentration can be detected. On the other hand, in $\left[\mathrm{NO}_{2}\right]$ time history intermittent events are rarely observed. This aspect is a footprint of chaotic behavior of the Rome in terms of pollutant generation and could be taken into account during the modelling stage of this process.

Instead $\left[\mathrm{NO}_{2}\right],\left[\mathrm{PM}_{2.5}\right],\left[\mathrm{PM}_{10}\right]$ and $\left[\mathrm{O}_{3}\right]$ have a distribution with a more flat trend. In particular, $\left[\mathrm{NO}_{2}\right] p d f$ is well fitted by the Gaussian $p d f$ except for a small region over $3 \sigma$ where a departure of the positive tail can be clearly observed. In the latter case, we can consider, in a first approximation, equally probable concentrations in a certain range.
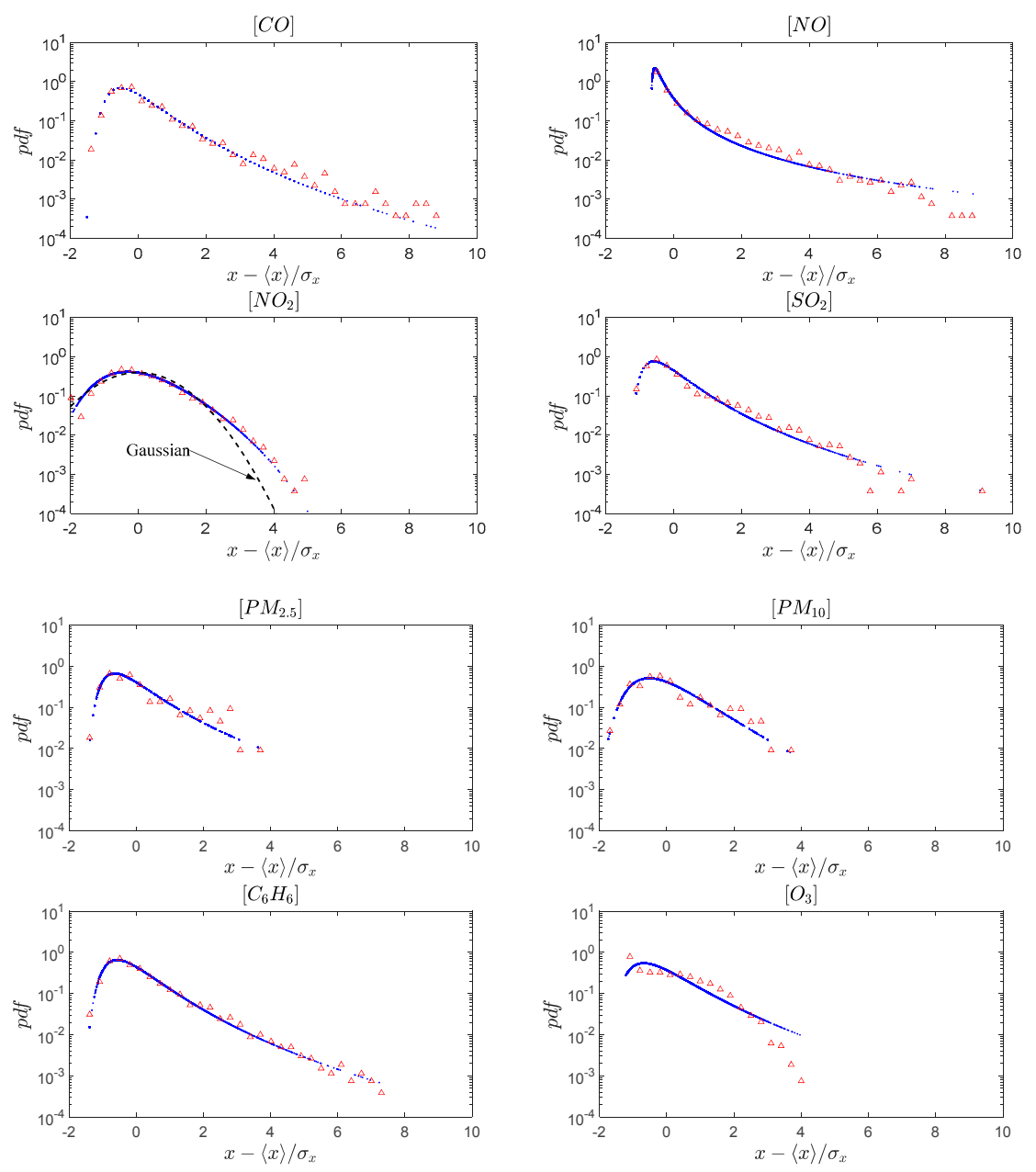

Figure 12. Probability density function (red triangles) and Generalized Extreme Value fitting (blue circles) of pollutant concentrations calculated for samples acquired in a year. 
Analysing the probability distributions in comparing with the standards reported in Table 1 , it could be notice that $\left[\mathrm{NO}_{2}\right],\left[\mathrm{PM}_{2.5}\right],\left[\mathrm{PM}_{10}\right],\left[\mathrm{C}_{6} \mathrm{H}_{6}\right]$ and $\left[\mathrm{O}_{3}\right]$ exceeds the limit of legislation during the year. In particular, $64 \%$ of time the $\left[\mathrm{NO}_{2}\right]$ was over the limit of $40 \mu \mathrm{g} / \mathrm{m}^{3}, 23 \%$ of time the $\left[\mathrm{PM}_{2.5}\right]$ was over the limit of $25 \mu \mathrm{g} / \mathrm{m}^{3}$, and $21 \%$ of time $\left[\mathrm{PM}_{10}\right]$ was over the limit of $40 \mu \mathrm{g} / \mathrm{m}^{3}$. Regarding the concentration of $\left[\mathrm{C}_{6} \mathrm{H}_{6}\right]$ and $\left[\mathrm{O}_{3}\right]$ the time in which the concentration is over the limit of legislation is less than previous pollutant: $4 \%$ of time the $\left[\mathrm{C}_{6} \mathrm{H}_{6}\right]$ was over the limit of $40 \mu \mathrm{g} / \mathrm{m}^{3}$ and $3 \%$ of time the $\left[\mathrm{O}_{3}\right]$ was over the limit of $120 \mu \mathrm{g} / \mathrm{m}^{3}$.

In 2015, regarding the limit in the short averaging period (from 1 to $24 \mathrm{~h}$ ), $\left[\mathrm{NO}_{2}\right],\left[\mathrm{SO}_{2}\right]$ and [CO] haven't exceeded the legislation thresholds. For $\left[\mathrm{PM}_{10}\right]$ the limit of $50 \mu \mathrm{g} / \mathrm{m}^{3}$ for an averaging period of $24 \mathrm{~h}$ was exceeded 39 times that is more than 35 permitted exceedances each year by the legislation. These exceedances are concentrated in December when there was a combination of exogenous state variable (i.e., temperature, humidity and wind velocity and direction, and traffic flow) and low rainfall. For $\left[\mathrm{O}_{3}\right]$ the limit of $120 \mu \mathrm{g} / \mathrm{m}^{3}$ for an averaging period of $8 \mathrm{~h}$ was exceeded 7 times. For this concentration, the legislation permitted 25 exceedances days over 3 years.

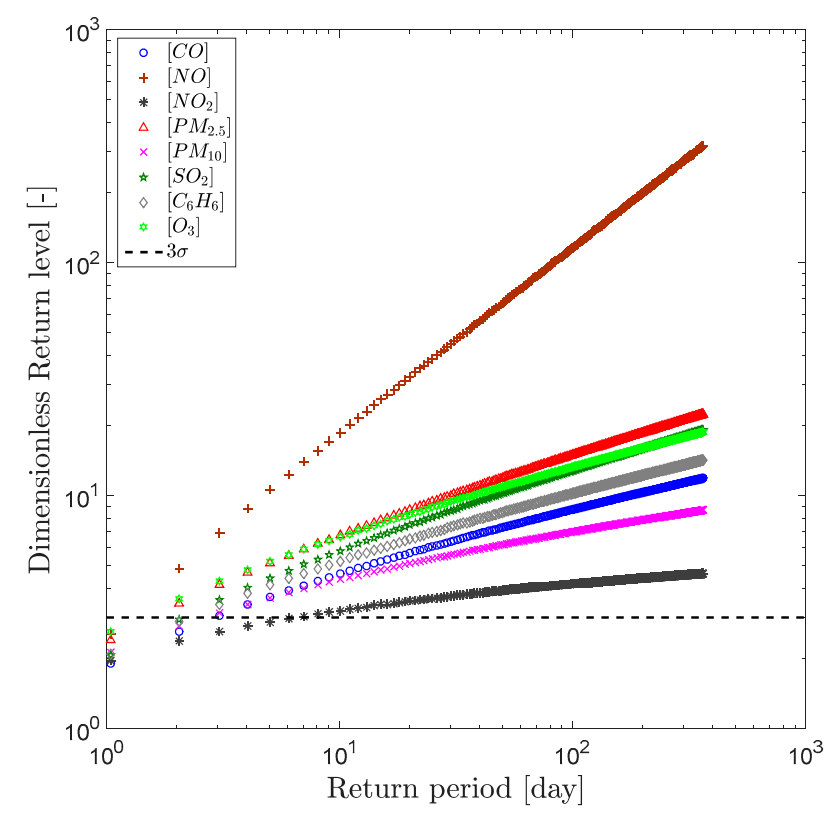

Figure 13. Dimensionless Return level trend for all the pollutant concentrations.

As stated previously and as further confirmed by the values assumed by Kurtosis and Skewness (see Table 3), with reference to the set of [CO], [NO], $\left[\mathrm{SO}_{2}\right]$ and $\left[\mathrm{C}_{6} \mathrm{H}_{6}\right]$ a high Kurtosis value is evaluated, indicating that these pollutants are present on Rome in constant quantities. On the other hand the high Kurtosis values suggests a sharped distribution around the mode. Whereas the coefficient of variation of [NO] have large value indicating that there are high energetic extreme value (see Figure 12).

Table 3. Kurtosis and Skewness values calculated for all pollutant species.

\begin{tabular}{cccc}
\hline Specie & Kurtosis & Skewness & Coefficient of Variation \\
\hline$[\mathrm{CO}]$ & 14.3 & 2.7 & $66 \%$ \\
{$[\mathrm{NO}]$} & 17.1 & 3.3 & $155 \%$ \\
{$\left[\mathrm{SO}_{2}\right]$} & 9.6 & 2.2 & $91 \%$ \\
{$\left[\mathrm{C}_{6} \mathrm{H}_{6}\right]$} & 9.4 & 2.1 & $72 \%$ \\
{$\left[\mathrm{NO}_{2}\right]$} & 3.9 & 0.7 & $48 \%$ \\
{$\left[\mathrm{PM}_{2.5}\right]$} & 4.2 & 1.3 & $60 \%$ \\
{$\left[\mathrm{PM}_{10}\right]$} & 3.7 & 1.0 & $46 \%$ \\
{$\left[\mathrm{O}_{3}\right]$} & 2.8 & 0.7 & $80 \%$ \\
\hline
\end{tabular}


In the case of $\left[\mathrm{NO}_{2}\right]$ the values assumed by the Kurtosis are close to those of a Gaussian distribution as confirmed by the comparison in Figure 12, indicating the presence of a species of pollutant that fluctuate significantly around an average value.

Given that the most important benzene source is the urban traffic, the concentration of benzene may be used as an index of city traffic flux and its time history can be taken into account as reference. The production of benzene is characterized by small oscillations in Rome during the time window investigated. Furthermore, $\left[\mathrm{C}_{6} \mathrm{H}_{6}\right]$ are strongly related to the concentration of pollutants species such as [CO], [NO] and $\left[\mathrm{NO}_{2}\right]$, as confirmed by the cross-correlation values reported in Figure 14 . This correlation is due to the fact that nitrogen oxide and carbon oxides are combustion products and that their fluctuations are due to the oscillations of the city traffic flux. It is noteworthy that $\left[\mathrm{O}_{3}\right]$ is weakly related to the production of benzene but it is indeed in phase opposition with it. To further investigate this interesting aspect, the Poincaré section of $\left[\mathrm{C}_{6} \mathrm{H}_{6}\right]$ upon $[\mathrm{NO}]$ and $\left[\mathrm{C}_{6} \mathrm{H}_{6}\right]$ upon $\left[\mathrm{O}_{3}\right]$ are represented in Figure 15. As noted above there is a strong linear dependence between $\left[\mathrm{C}_{6} \mathrm{H}_{6}\right]$ and [NO] and a more complex interdependence of $\left[\mathrm{O}_{3}\right]$ and $\left[\mathrm{C}_{6} \mathrm{H}_{6}\right]$. More specifically an inverse proportionality is clearly observed as formalized in the following:

$$
\left|\frac{d\left[\mathrm{C}_{6} \mathrm{H}_{6}\right]}{d t}\right| \sim-\left|\frac{d\left[\mathrm{O}_{3}\right]}{d t}\right|
$$
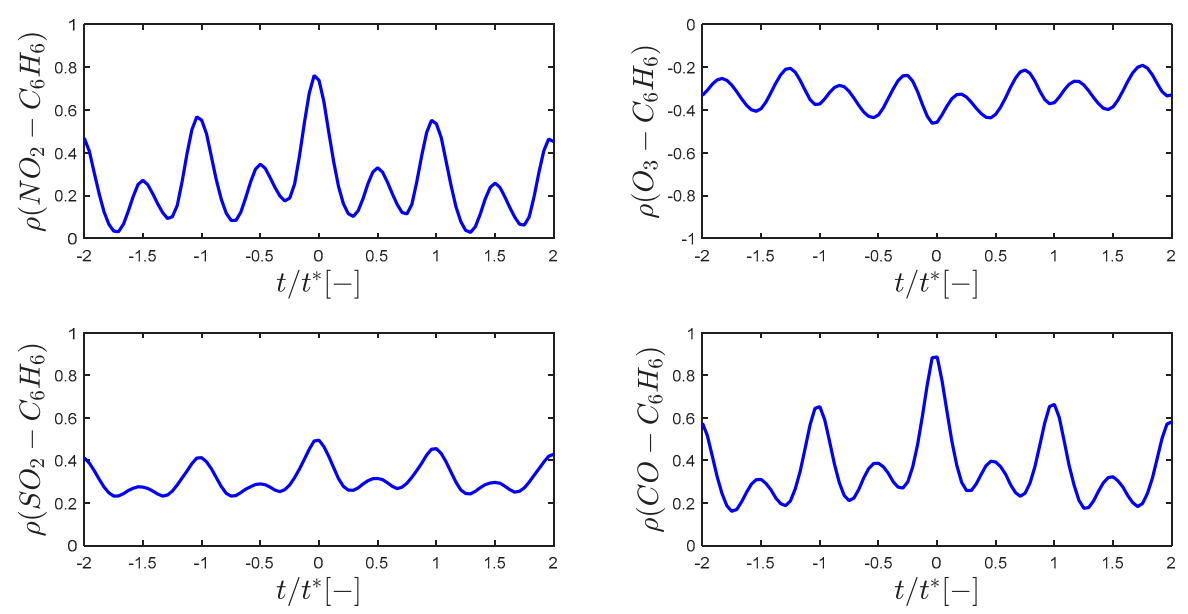

Figure 14. Cross-correlation between pollutant concentrations; benzene concentration is taken into account as a reference signal; the time axis is normalized respect to a reference time: $t^{*}=86,400 \mathrm{~s}$.
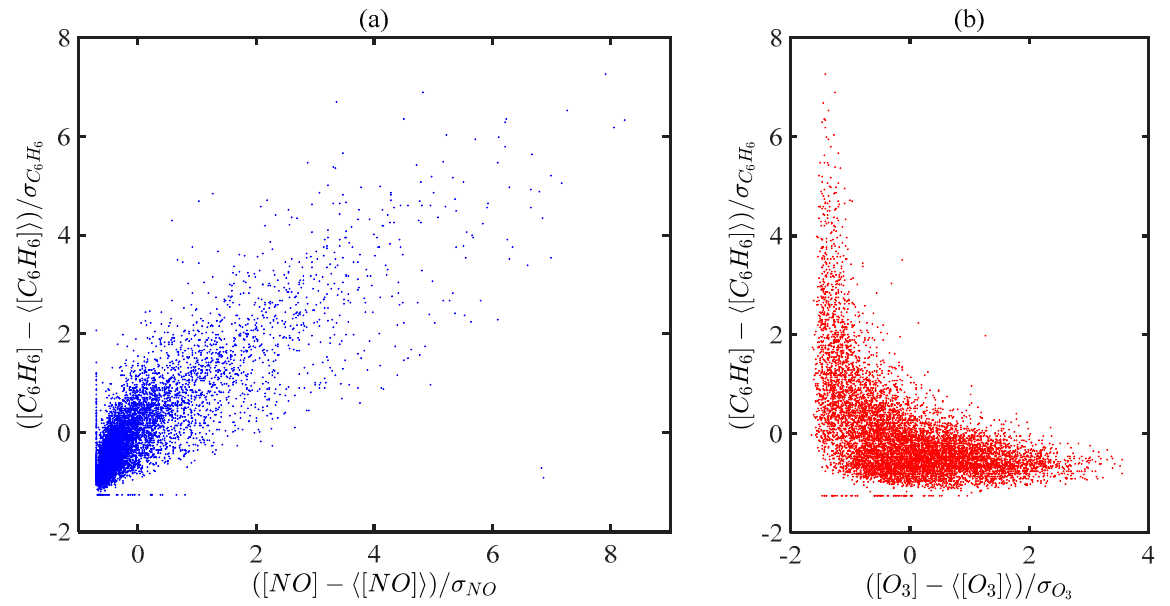

Figure 15. Poincaré sections $\left[\mathrm{C}_{6} \mathrm{H}_{6}\right]$ over $[\mathrm{NO}](\mathbf{a})$ and $\left[\mathrm{C}_{6} \mathrm{H}_{6}\right]$ over $\left[\mathrm{O}_{3}\right](\mathbf{b})$. 
Qualitatively is provided that to a reduction of $\left[\mathrm{C}_{6} \mathrm{H}_{6}\right]$ under a certain threshold level corresponds an increase of $\left[\mathrm{O}_{3}\right]$. Such behaviour could be attributed to exogenous state variable, which were not taken into account in the present work.

\section{Conclusions}

Observance of air quality standards represents a great challenge in cities, especially in the ones in which traffic and other additional sources are combined with bad weather conditions. With reference to this issue, the results herein provided shown that the major pollutant concentrations are observed in the winter seasons during the intense traffic flow and the threshold values are often exceeded. Furthermore, according to the coefficient of variation values, Rome has a strongly unsteady behaviour in terms of a family of pollutant concentration which fluctuate significantly.

$\left[\mathrm{C}_{6} \mathrm{H}_{6}\right]$ are strongly related to the concentration of pollutants species such as [CO], [NO] and $\left[\mathrm{NO}_{2}\right]$, as confirmed by the cross-correlation analysis. This correlation is due to the fact that nitrogen oxide prompts and carbon oxides are combustion products and that their fluctuations are caused by the oscillations of the city traffic flux. $\left[\mathrm{O}_{3}\right]$ is weakly related to the production of benzene and it is also in phase opposition with it. For this reason, the Poincare section of $\left[\mathrm{C}_{6} \mathrm{H}_{6}\right]$ upon $[\mathrm{NO}]$ and $\left[\mathrm{C}_{6} \mathrm{H}_{6}\right]$ upon $\left[\mathrm{O}_{3}\right]$ was investigated. It is worth noticing that there is a strong linear dependence between $\left[\mathrm{C}_{6} \mathrm{H}_{6}\right]$ and $[\mathrm{NO}]$ and a more complex interdependence of $\left[\mathrm{O}_{3}\right]$ and $\left[\mathrm{C}_{6} \mathrm{H}_{6}\right]$. Qualitatively is provided that, to a reduction of $\left[\mathrm{C}_{6} \mathrm{H}_{6}\right]$ under a certain threshold level which corresponds to an increase of $\left[\mathrm{O}_{3}\right]$. Such behaviour could be attributed to exogenous state variable.

The main objective for the reduction of air pollutant is to reach, thanks to the implementation of suitable mobility policies, an urban sustainable development, i.e., to improve traffic mobility conditions, to increase road safety and to decrease traffic caused by pollution and to re-qualify urban spaces. It includes rationalizing public space, safeguarding citizens' health and life quality, and preserving historical and architectural heritage.

The government is promoting both long and short-term activities to reach these goals. From the analysis of the current air situation, it is clear that traffic is the reason why the pollutant concentrations are so high. Traffic is the main source of $[\mathrm{CO}],\left[\mathrm{C}_{6} \mathrm{H}_{6}\right]$ and $\left[\mathrm{PM}_{10}\right]$ concentrations.

In order to reduce the pollution in Italian cities and in particular in Rome, measures are needed to decrease the level of the various substances dispersed into the air. One of the main actions that can be performed is the reduction or elimination of the use of the most polluting cars, i.e., cars Euro 0,1 and 2. As a matter of fact, Roma Capitale has imposed the circulation reduction of these cars permanently from 15 December 2015 [46].

Regarding the reduction of the pollutants due to buildings heating systems, it is necessary to replace traditional boilers with more efficient systems, such as condensing boilers. As a matter of fact, the condensing boilers allow reducing the utilization of combustion and a consequence decrease of emission.

However, the boilers are only one element of the heating systems. Its efficiency depends on other elements such as distribution, emission and regulation. Using condensing boilers coupled with other high heating systems elements, can improve the total efficiency and reduce the environmental emission.

The Poincaré sections in Figure 15 gives a significant contribution to the modeling purpose: such as dynamical model (ODE) or regression approach (LUR) (see among many [47,48]).

More specifically, the experimental analysis shows a correlation between $\left[\mathrm{C}_{6} \mathrm{H}_{6}\right]$ over $[\mathrm{NO}]$ and $\left[\mathrm{C}_{6} \mathrm{H}_{6}\right]$ over $\left[\mathrm{O}_{3}\right]$. These aspects are well known for small scale zero-dimensional reactor, but for very large scale problems as the city domain is not commonly investigated. Therefore, a reduction of a three dimensional large scale process to zero-dimensional phenomenon as in homogeneous volume can be consider the first step for a mathematical model development by means of an ODE system as follows:

$$
x=f[x(t)] \text { where } x(t)=\left\{[\mathrm{NO}],\left[\mathrm{O}_{3}\right],\left[\mathrm{C}_{6} \mathrm{H}_{6}\right], \ldots\right\}
$$


This aspect is the fundamental task to predict the time evolution of the pollutant species generated within an urban domain.

Furthermore, as a result, it can be clearly concluded that Rome has a strongly unsteady behaviour in terms of pollutant concentration. All-time series are positive skewed, indicating that some short time rare events, of pollutant concentration, have an order of magnitude bigger than the expected values. Such as intermittent behaviour must be taken into account for modelling purpose.

Acknowledgments: The authors are grateful to ARPA Lazio which provided the experimental data.

Author Contributions: The work was designed by Gabriele Battista, Tiziano Pagliaroli and Roberto De Lieto Vollaro. Gabriele Battista and Tiziano Pagliaroli wrote the paper and perform the statistic and cross-statistic analysis. English corrections were revised by Luca Mauri and Carmine Basilicata. Finally, Roberto De Lieto Vollaro supervised the work related to the paper. All authors read and approved the final manuscript.

Conflicts of Interest: The authors declare no conflict of interest.

\section{References}

1. International Agency for Research on Cancer (IARC). Outdoor air pollution. In IARC Monograph on the Evaluation of Carcinogenic Risks to Humans; International Agency for Research on Cancer: Lyon, France, 2015; Volume 109.

2. Mayer, H. Air pollution in cities. Atmos. Environ. 1999, 33, 4029-4037. [CrossRef]

3. Guerrieri, M.; Corriere, F.; Rizzo, G.; Casto, B.L.; Scaccianoce, G. Improving the Sustainability of Transportation: Environmental and Functional Benefits of Right Turn by-Pass Lanes at Roundabouts. Sustainability 2015, 7, 5838-5856. [CrossRef]

4. Schiavon, M.; Redivo, M.; Antonacci, G.; Rada, E.C.; Ragazzi, M.; Zardi, D.; Giovannini, L. Assessing the air quality impact of nitrogen oxides and benzene from road traffic and domestic heating and the associated cancer risk in an urban area of Verona (Italy). Atmos. Environ. 2015, 120, 234-243. [CrossRef]

5. Lim, S.S.; Vos, T.; Flaxman, A.D.; Danaei, G.; Shibuya, K.; Adair-Rohani, H.; Adair-Rohani, H.; Amann, M.; Anderson, H.R.; Andrews, K.G.; et al. A comparative risk assessment of burden of disease and injury attributable to 67 risk factors and risk factor clusters in 21 regions, 1990-2010: A systematic analysis for the Global Burden of Disease Study 2010. Lancet 2013, 380, 2224-2260. [CrossRef]

6. Straif, K.; Cohen, A.; Samet, J. Air Pollution and Cancer. IARC Scientific Publication No. 161; International Agency for Research on Cancer: Lyon, France, 2015.

7. Ghedini, N.; Gobbi, G.; Sabbioni, C.; Zappia, G. Determination of elemental and organic carbon on damaged stone monuments. Atmos. Environ. 2000, 34, 4383-4391. [CrossRef]

8. Coppi, M.; Quintino, A.; Salata, F. Numerical study of a vertical channel heated from below to enhance natural ventilation in a residential building. Int. J. Vent. 2013, 12, 41-49. [CrossRef]

9. Salata, F.; Golasi, I.; de Lieto Vollaro, E.; Bisegna, F.; Nardecchia, F.; Coppi, M.; Gugliermetti, F.; de Lieto Vollaro, A. Evaluation of different urban microclimate mitigation strategies through a PMV analysis. Sustainability 2015, 7, 9012-9030. [CrossRef]

10. De Lieto Vollaro, R.; Evangelisti, L.; Carnielo, E.; Battista, G.; Gori, P.; Guattari, C.; Fanchiotti, A. An Integrated Approach for an Historical Buildings Energy Analysis in a Smart Cities Perspective. Energy Procedia 2014, 45, 372-378. [CrossRef]

11. Evangelisti, L.; Battista, G.; Guattari, C.; Basilicata, C.; de Lieto Vollaro, R. Influence of the Thermal Inertia in the European Simplified Procedures for the Assessment of Buildings' Energy Performance. Sustainability 2014, 6, 4514-4524. [CrossRef]

12. Salata, F.; de Lieto Vollaro, A.; de Lieto Vollaro, R.; Davoli, M. Plant reliability in hospital facilities. Energy Procedia 2014, 45, 1195-1204. [CrossRef]

13. Evangelisti, L.; Battista, G.; Guattari, C.; Basilicata, C.; de Lieto Vollaro, R. Analysis of Two Models for Evaluating the Energy Performance of Different Buildings. Sustainability 2014, 6, 5311-5321. [CrossRef]

14. De Lieto Vollaro, R.; Vallati, A.; Bottillo, S. Differents Methods to Estimate the Mean Radiant Temperature in an Urban Canyon. Adv. Mater. Res. 2013, 650, 647-651. [CrossRef]

15. D'Orazio, A.; Fontana, L.; Salata, F. Experimental study of a semi-passive ventilation grille with a feedback control system. Rev. Sci. Instrum. 2011, 82, 085107. [CrossRef] [PubMed] 
16. Coppi, M.; Quintino, A.; Salata, F. Fluid dynamic feasibility study of solar chimney in residential buildings. Int. J. Heat Technol. 2011, 29, 1-5.

17. Salata, F.; Golasi, I.; de Lieto Vollaro, R.; de Lieto Vollaro, A. Outdoor thermal comfort in the Mediterranean area. A transversal study in Rome, Italy. Build. Environ. 2016, 96, 46-61. [CrossRef]

18. Salata, F.; Alippi, C.; Tarsitano, A.; Golasi, I.; Coppi, M. A first approach to natural thermoventilation of residential buildings through ventilation chimneys supplied by solar ponds. Sustainability 2015, 7, 9649-9663. [CrossRef]

19. Vallati, A.; De Lieto Vollaro, A.; Golasi, I.; Barchiesi, E.; Caranese, C. On the impact of urban micro climate on the energy consumption of buildings. Energy Procedia 2015, 82, 506-511. [CrossRef]

20. Battista, G.; Carnielo, E.; Evangelisti, L.; Frascarolo, M.; de Lieto Vollaro, R. Energy Performance and Thermal Comfort of a High Efficiency House: RhOME for denCity, Winner of Solar Decathlon Europe 2014. Sustainability 2015, 7, 9681-9695. [CrossRef]

21. Memon, R.A.; Leung, D.Y.C.; Liu, C. An investigation of urban heat island intensity (UHII) as an indicator of urban heating. Atmos. Res. 2009, 94, 491-500. [CrossRef]

22. Goia, F.; Zinzi, M.; Carnielo, E.; Serra, V. Characterization of the optical properties of a PCM glazing system. Energy Procedia 2012, 30, 428-437. [CrossRef]

23. Paolini, R.; Zinzi, M.; Poli, T.; Carnielo, E.; Mainini, A.G. Effect of ageing on solar spectral reflectance of roofing membranes: Natural exposure in Roma and Milano and the impact on the energy needs of commercial buildings. Energy Build. 2014, 84, 333-343. [CrossRef]

24. Goia, F.; Zinzi, M.; Carnielo, E.; Serra, V. Spectral and angular solar properties of a PCM-filled double glazing unit. Energy Build. 2015, 87, 302-312. [CrossRef]

25. Zinzi, M.; Carnielo, E.; Federici, A. Preliminary studies of a cool roofs' energy-rating system in Italy. Adv. Build. Energy Res. 2014, 8, 84-96. [CrossRef]

26. Carnielo, E.; Zinzi, M. Optical and thermal characterisation of cool asphalts to mitigate urban temperatures and building cooling demand. Build. Environ. 2013, 60, 56-65. [CrossRef]

27. De Lieto Vollaro, A.; Galli, G.; Vallati, A.; Romagnoli, R. Analysis of thermal field within an urban canyon with variable thermophysical characteristics of the building's walls. J. Phys. Conf. Ser. 2015, 655, 012056. [CrossRef]

28. De Lieto Vollaro, A.; Galli, G.; Vallati, A. CFD Analysis of Convective Heat Transfer Coefficient on External Surfaces of Buildings. Sustainability 2015, 7, 9088-9099. [CrossRef]

29. Chan, A.T.; So, E.S.P.; Samad, S.C. Strategic guidelines for street canyon geometry to achieve sustainable street air quality. Atmos. Environ. 2001, 35, 4089-4098. [CrossRef]

30. Oke, T.R. Street design and urban canopy layer climate. Energy Build. 1988, 11, 103-111. [CrossRef]

31. Britter, R.E.; Hanna, S.R. Flow and dispersion in urban areas. Annu. Rev. Fluid Mech. 2003, 35, 469-496. [CrossRef]

32. Fisher, R.A.; Tippett, L.H.C. Limiting forms of the frequency distribution of the largest or smallest member of a sample. Math. Proc. Camb. Philos. Soc. 1928, 24, 180-190. [CrossRef]

33. Martins, E.S.; Stedinger, J.R. Generalized maximum-likelihood generalized extreme-value quantile estimators for hydrologic data. Water Resour. Res. 2000, 36, 737-744. [CrossRef]

34. Kütchenhoff, H.; Thamerus, M. Extreme value analysis of Munich air pollution data. Environ. Ecol. Stat. 1996, 3, 127-141. [CrossRef]

35. Smith, R.L. Extreme Value Analysis of Environmental Time Series: An Application to Trend Detection in Ground-Level Ozone. Stat. Sci. 1989, 4, 367-377. [CrossRef]

36. Rao, S.T.; Sistla, G.; Henry, R. Statistical analysis of trends in urban ozone air quality. J. Air Waste Manag. Assoc. 1992, 42, 1204-1211. [CrossRef]

37. Nor, A.M.A.; Mohd, B.A.; Ahmad, Z.A. Bayesian Extreme for Modeling High PM $\mathrm{P}_{10}$ Concentration in Johor. Procedia Environ. Sci. 2015, 30, 309-314.

38. Shi, L.; Stuart, B.; Feng-Chiao, S.; Bhramar, M. Addressing extrema and censoring in pollutant and exposure data using mixture of normal distributions. Atmos. Environ. 2013, 77, 464-473.

39. Shen, L.; Mickley, L.J.; Gilleland, E. Impact of increasing heat waves on US ozone episodes in the 2050s: Results from a multimodel analysis using extreme value theory. Geophys. Res. Lett. 2016, 43, 4017-4025. [CrossRef] [PubMed] 
40. Roma Capitale, Piano Generale del Traffico Urbano (in English: City Urban Traffic General Plan). April 2015. Available online: https://www.comune.roma.it/pcr/it/dip_mob_delibere.page (accessed on 22 August 2016).

41. United States Environmental Protection Agency (EPA). Air Quality Planning and Standards. Available online: https://www3.epa.gov/airquality/ (accessed on 22 August 2016).

42. European Commission. Available online: http:/ /ec.europa.eu/ (accessed on 22 August 2016).

43. European Union. Directive 2008/50/EC of the European Parliament and of the Council of 21 May 2008 on Ambient Air Quality and Cleaner Air for Europe. Available online: http:/ / eur-lex.europa.eu/LexUriServ/ LexUriServ.do?uri=OJ:L:2008:152:0001:0044:en:PDF (accessed on 22 August 2016).

44. ARPA Lazio-Centro Regionale della Qualità dell'Aria (in English: Regional Center of Air Quality). Available online: http:/ /www.arpalazio.net/ (accessed on 22 August 2016).

45. ARPA Lazio. Valutazione della Qualità dell'aria-2015 (In English: Air Quality Assessment-2015). RT/DAI/16/01; ARPA Lazio: Rieti, Italy, 2015.

46. Roma Capitale, Fascia Verde e Anello Ferroviario (in English: Green Band and Ring Rail). Available online: http://www.agenziamobilita.roma.it/it/servizi/orari-ztl/fascia-verde-anello-ferroviario.html (accessed on 22 August 2016).

47. Beelen, R.; Hoek, G.; Vienneau, D.; Eeftens, M.; Dimakopoulou, K.; Pedeli, X.; Tsai, M.; Künzli, N.; Schikowski, T.; Marcon, A.; et al. Development of $\mathrm{NO}_{2}$ and $\mathrm{NO}_{\mathrm{x}}$ land use regression models for estimating air pollution exposure in 36 study areas in Europe-The ESCAPE project. Atmos. Environ. 2013, 72, 10-23. [CrossRef]

48. Eeftens, M.; Beelen, R.; de Hoogh, K.; Bellander, T.; Cesaroni, G.; Cirach, M.; Declercq, C.; Dèdele,, A.; Dons, E.; de Nazelle, A.; et al. Development of land use regression models for PM2.5, PM2.5 absorbance, PM10 and PMcoarse in 20 European study areas; results of the ESCAPE project. Environ. Sci. Technol. 2012, 46, 11195-11205. [CrossRef] [PubMed]

(C) 2016 by the authors; licensee MDPI, Basel, Switzerland. This article is an open access article distributed under the terms and conditions of the Creative Commons Attribution (CC-BY) license (http:/ / creativecommons.org/licenses/by/4.0/). 